\title{
THE SACHEM:
}

\section{A NEW SKIPPER FOR MANITOBA AND THE PRAIRIE PROVINCES}

\section{PETER TAYLOR, Box 597, Pinawa, Manitoba. R0E 1 Lo}

The afternoon of 9 July 1991 was ideal for butterfly watching in southeastern Manitoba - sunny, but not too warm, with light winds and plenty of moisture after a wet weekend. I spent much of the afternoon counting and photographing butterflies along Provincial Road 308, south of East Braintree. This lightly used stretch of gravel road passes through a variety of forest habitats, and is about $60 \mathrm{~km}$ from the nearest extensive agricultural region.

Of particular interest was a small, newly discovered population of the Baltimore, Euphydryas phaeton (Drury), a rare species in Manitoba. ${ }^{4,6,10}$ Among the skippers, the Dun Skipper, Euphyes ruricola (Boisduval), was exceptionally common, and there were also numbers of the European Skipper, Thymelicus lineola (Ochsenheimer) and a few individuals of the Long Dash, Polites mystic (W.H. Edwards).

One roadside patch of Canada Thistle, Cirsium arvense (L.) Scop., about $18 \mathrm{~km}$ s.s.e. of East Braintree $\left(49^{\circ}\right.$ $30^{\prime} \mathrm{N}, 95^{\circ} 32^{\prime} \mathrm{W}$ ) had attracted a fine variety of butterflies. While engaged in photography I noticed an unfamiliar skipper nectaring on a thistle flower. Large and robust, relative to the three species listed above, it resembled a female Hesperia. It was quite worn and faded, and the most prominent features were two large, almost transparent spots near the centre of each forewing. I obtained a series of six photographs before the skipper flew away, after which it could not be relocated.
Comparison of the slides with plates in Opler and Krizek's Butterflies East of the Great Plains led to the tentative identification of this skipper as a female Sachem (sometimes spelled Satchem and also known as Field Skipper), Atalopedes campestris (Boisduval). ${ }^{7}$ The photographs did not match well with any known Manitoban species. ${ }^{4}$ I therefore sought advice in confirming the skipper's identity.

Two Manitoban lepidopterists, Paul Klassen and Richard Westwood, agreed that the identification could be correct, but suggested that I seek an opinion from an authority more familiar with the species. Four slides were sent to Paul Opler (U. S. Fish and Wildlife Service, Fort Collins, Colorado), who confirmed the skipper's identification as a female Sachem. Two of these slides, showing dorsal views of the skipper, are reproduced here.

The Sachem is resident across much of the southern United States from Virginia to California and south to Brazil. ${ }^{7,9}$ It is a temporary summer visitor and sporadic breeder as far north as southern Ontario and much of the northern United States, and it has been recorded in British Columbia. ${ }^{1,2,5,7,8,9}$ In North Dakota, McCabe and Post distinguish two flight periods, 10 June-25 July and 25 August-5 October; the Manitoba record lies well within the former period. $^{5}$ While there is general agreement that the Sachem cannot withstand severe winters, McCabe 


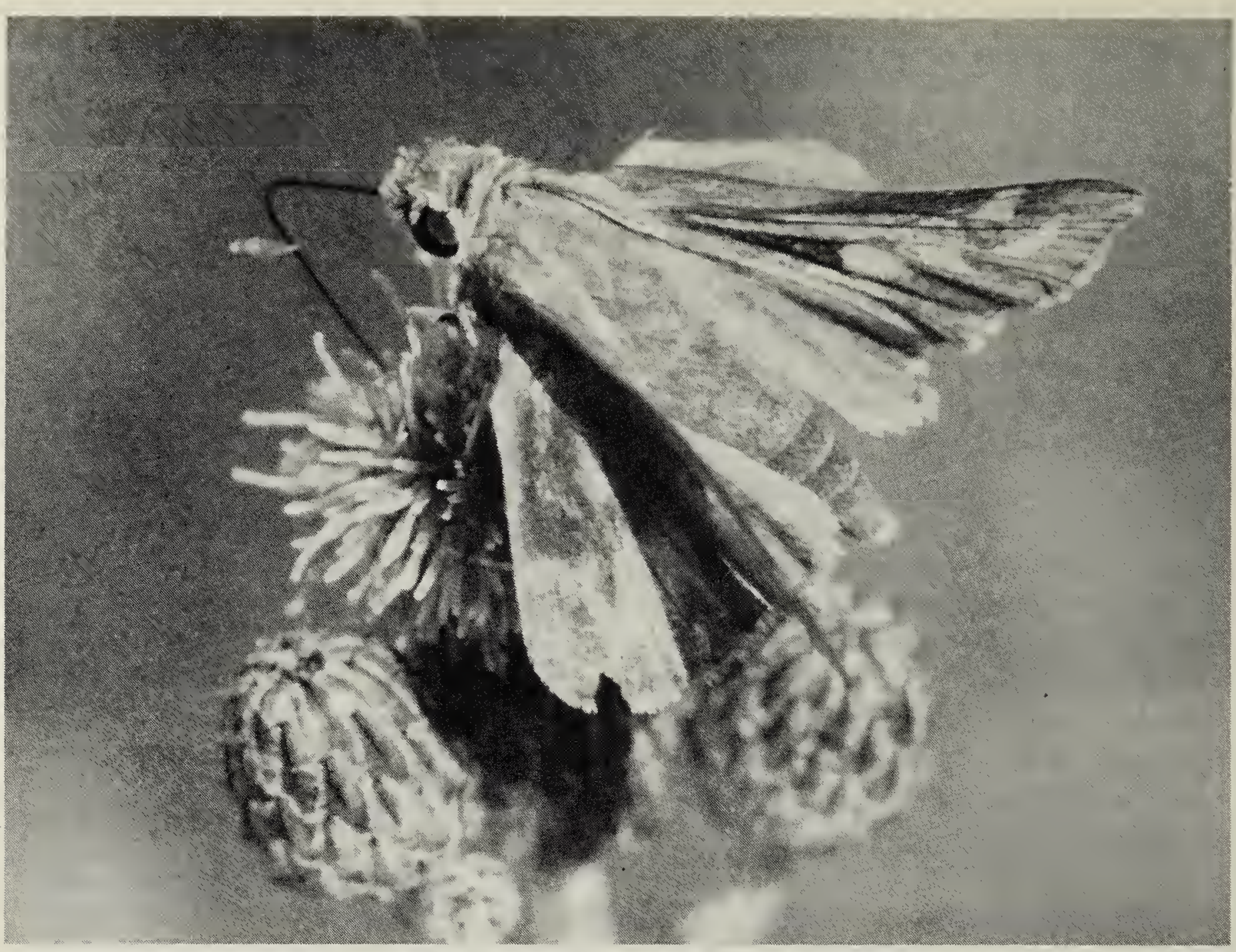

Female Sachem near East Braintree, MB, 9 July 1991; dorsal view.

Peter Taylor

and Post suggest that winter survival may be possible in the southern badlands of North Dakota. ${ }^{5}$ They note that the spring brood is absent after harsh winters, but can be abundant in June after mild winters.

Although their distribution map shows specimen locations only in the southern third of North Dakota, McCabe and Post indicate that the Sachem may occur as far north as the Pembina Hills and Turtle Mountains in good years; these regions adjoin Manitoba. ${ }^{5}$ Royer shows one additional specimen location in Grand Forks County, about 100 km from the Manitoba border, and 200 $\mathrm{km} \mathrm{s.w.} \mathrm{of} \mathrm{the} \mathrm{East} \mathrm{Braintree} \mathrm{site.}{ }^{8}$ Seasonal reports published by the Lepidopterists' Society indicate that the Sachem staged a significant flight into the north-central United States in late June and early July $1991 .{ }^{6}$ The species was reported from seven Wisconsin counties, in- cluding four new county records, and two new county records were reported for North Dakota. Of particular interest was a report from Kittson Co., at the northwestern extremity of Minnesota, only about $120 \mathrm{~km}$. S.w. of East Braintree, on 26 June 1991. ${ }^{6}$

It is possible that some Manitoba records of the Assiniboia Skipper, Hesperia comma assiniboia (Lyman), for 22 June to 11 July, which are questioned by Klassen et al., are referable to female Sachems. ${ }^{4}$ The female Sachem is well illustrated in several sources, ${ }^{5,7,8}$ but many of the commonly used field guides lack illustrations or detailed descriptions, making identification difficult. Furthermore, the insect is quite variable, and the individual illustrated in Howe's Butterflies of North America is extremely dark. ${ }^{3}$

Given the wide-ranging, sporadic northward movements of the Sachem, 


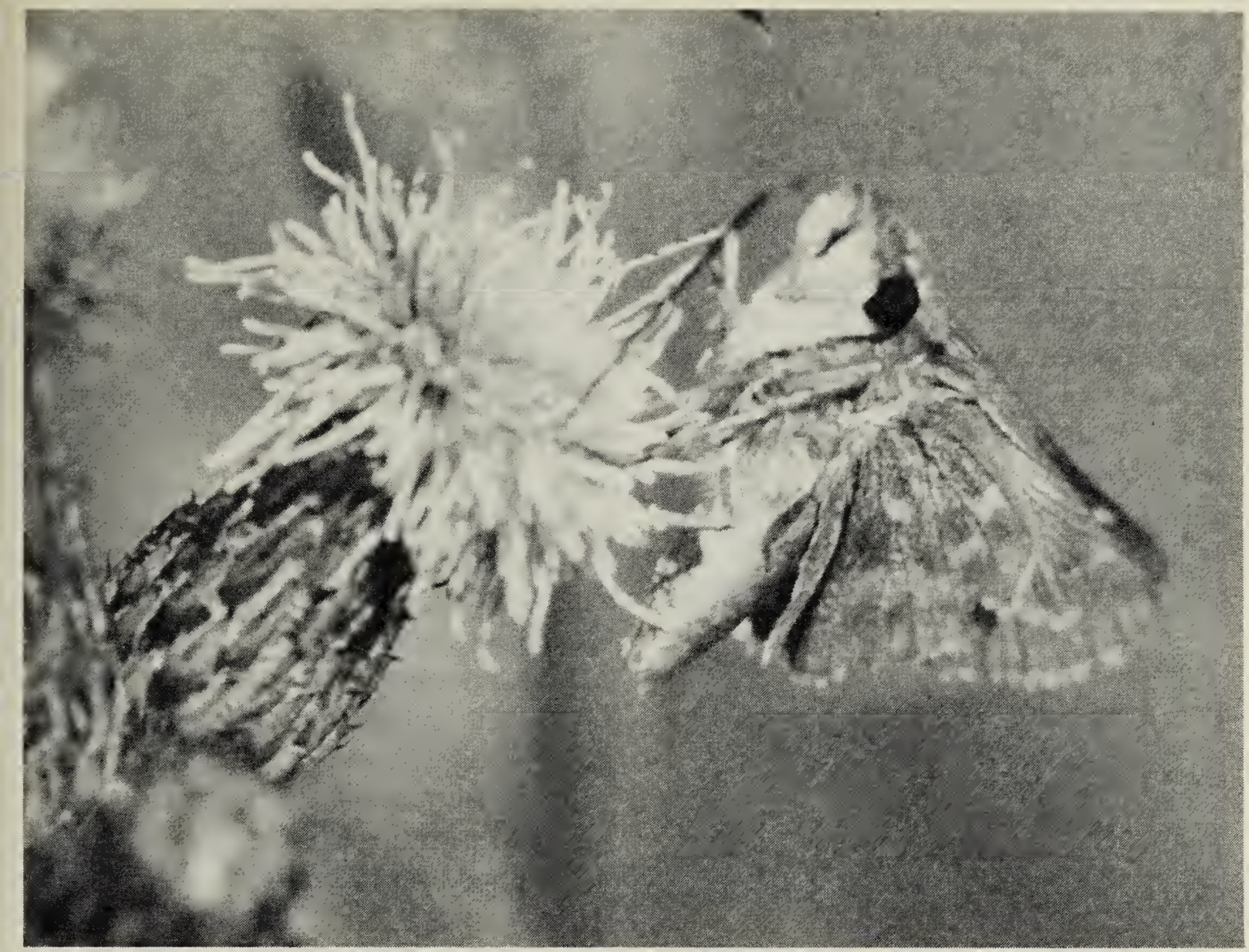

Female Sachem near East Braintree, MB, 9 July 1991; dorsal view.

Peter Taylor

its occurrence in Manitoba from time to time would not be surprising. The worn condition of the individual described here is consistent with long-distance immigration. Sachem larvae feed on various grasses, including Crabgrass (Digitaria sp.), so breeding in Manitoba may be possible if the Sachem ever reaches the province in sufficient numbers. ${ }^{7}$

I thank Paul Klassen, Brian McKillop, Paul Opler, Bill Preston and Richard Westwood for their help and advice in verifying and documenting this record.

1. EBNER, J.A. 1970. The butterflies of Wisconsin. Milwaukee Public Museum Popular Science Handbook No. 12. 205 pp.

2. GREGORY, W.W. 1983. A revised check-list of the butterflies and skippers of Canada (Lepidoptera). Lyman Entomol. Mus. and Res. Lab. Memoir No. 14, p. 4.

3. HOWE, W. H. 1975. The butterflies of North America. Doubleday, Garden City, New York. 633 pp.
4. KLASSEN, P., A.R. WESTWOOD, W.B. PRESTON and W.B. MCKILLOP. 1989. The butterflies of Manitoba. Manitoba Mus. of Man and Nature, Winnipeg. 290 pp.

5. MCCABE, T.L. and R.L. POST. 1977. Skippers (Hesperioidea) of North Dakota (with additional records of North Dakota butterflies and a butterfly calendar). Dept. of Entomol. Agr. Expt. Stn. N. D. State Univ. 70 pp.

6. MCKOWN, S. (editor). 1992. 1991 season summary. News of the Lepidopterists' Society No. 2, Kansas. Mar/Apr 1992.

7. OPLER, P.A. and G.O. KRIZEK. 1984. Butterflies east of the Great Plains: an illustrated natural history. Johns Hopkins Univ. Press, Baltimore. 294 pp.

8. ROYER, R.A. 1988. Butterflies of North Dakota: an atlas and guide. Minot State Univ. Sci. Monograph No. 1. 192 pp.

9. SCOTT, J.A. 1986. The butterflies of North America: a natural history and field guide. Stanford Univ. Press, Stanford, California. 583 pp.

10. TAYLOR, P. 1991. Baltimores and Turtleheads. Bull. Man. Nat. Soc. 16(9):13. 